\title{
Üniversite Öğrencilerinin Umutsuzluk Düzeylerinin İncelenmesi: Ahi Evran Üniversitesi Örneği *
}

\author{
Kamile ŞANLI KULA, Turan SARAÇ*
}

\begin{abstract}
Üniversite Öğrencilerinin Umutsuzluk Düzeylerinin İncelenmesi: Ahi Evran Üniversitesi Örneği

Özet

Bu araştırmanın amacı, Ahi Evran Üniversitesinin dördüncü sınıfında öğrenim gören öğrencilerin umutsuzluk düzeylerini bazı değişkenler açısından incelemektir. Araştırmanın evreni 2013-2014 Eğitim-Öğretim Yılı Bahar Yarıyılı'nda sözkonusu üniversitenin dört yıllık eğitim veren fakülte ve yüksekokullarının dördüncü sınıflarında öğrenim gören 2489 öğrenciden oluşmaktadır. Verilerin toplanması aşamasında, Beck Umutsuzluk Ölçeği ve araştırmacı tarafından oluşturulan Kişisel Bilgi Formu kullanıımıştır. Toplanan verilerin analizinde frekans, yüzde, $t$-testi, varyans analizi ve Games-Howell testinden yararlanılmıştır. Araştırmanın sonuçlarına göre; cinsiyet, fakülte/yüksekokul, anne-baba tutumu ve ailenin ortalama aylık geliri değişkenlerine göre öğrencilerin umutsuzluk düzeyleri arasında anlamlı farklılıkların olduğu, barınılan yer değişkenine göre farklıık olmadığı belirlenmiştir.
\end{abstract}

Anahtar Kelimeler: Umut, Umutsuzluk, Üniversite öğrencisi, Beck Umutsuzluk Ölçeği.
Analyzing the Hopelessness Level of the University Students: Example of Ahi Evran University

Abstract

The purpose of this study is to investigate the hopelessness level of the senior students at Ahi Evran University in terms of some various variables. The population of the study consists of 2489 senior students from the faculties and colleges of this University in 2013-2014 Educational Year Spring Term. Data were collected by Beck Hopelessness Scale and Personal Information Form developed by the researcher. Data were analyzed by frequency, percentage, t-test, variance analyze and Games-Howell test. According to the results of the study, there were differences between the hopelessness levels of the students in terms of gender, faculty/college, parent attitude and average monthly income variants. There weren't differences between hopelessness level and accommodation.

Key Words: Hope, Hopelessness, University Student, Beck Hopelessness Scale.

\section{Giriş}

Umut ve umutsuzluk, bireyin geleceğe yönelik beklentilerinin gerçekleşme imkanını ifade eder. Umutsuzluk, bireylerin başarısızlıklarını hiçbir zaman yenemeyeceklerini, problemlerini hiçbir zaman çözemeyeceklerine inanması, gerçekçi bir nedeni olmadığı halde yaşantılarına yanlış anlamlar yüklemesi ve amacına ulaşmak için çabalamadığı halde bunlardan negatif sonuçlar beklemesi şeklinde tarif edilmektedir (Beck, 1963) (Akt. A. Şahin, 2002). Umut gelecekle ilgili bir amacı gerçekleştirmede sıfırdan fazla olan beklentilerdir (Rideout ve Montemuro, 1986) (Akt. Dilbaz ve Seber, 1993). Bir çıkış

\footnotetext{
* Bu çalışma "Ahi Evran Üniversitesi Son Sınıf Öğrencilerinin Gelecek Kaygısı ve Umutsuzluklarının İncelenmesi” isimli yüksek lisans tez çalışmasının bir parçasıdır.

** Kamile ŞANLI KULA, Prof.Dr., Ahi Evran Üniversitesi, Matematik Bölümü, sanli2004@hotmail.com; Turan SARAÇ, Öğrt., Çiçekdağı Mesleki ve Teknik Eğitim Merkezi, turan_35_40@hotmail.com
} 
yolu olduğuna ve yardım ile bireyin varlığında değişiklikler oluşabileceği inancı umudun en önemli özelliğidir. Umutsuzluk ise bir amacı gerçekleştirmede sıfırdan az olan olumsuz beklentiler şeklinde tanımlanır. Gerek umut gerekse umutsuzluk, her ikisi de kişinin gelecekteki gerçek hedeflerine ulaşma olanaklarının olası yansımasıdır. Umut ve umutsuzluk karşıt beklentileri simgeler. Umutta hedefe ulaşmak için uygulamaya konulan planların başarılacağı öngörüsü varken, umutsuzlukta başarısızlık yargısı vardır. Bu iki üç beklenti kişiden kişiye, durumdan duruma beklenen sonucun ne zaman ve nasıl gerçekleştiğine bağlı olarak değişiklik gösterir (Melges, 1969) ( Akt. Dilbaz ve Seber, 1993).

Üngören ve Ehtiyar (2009), umutsuzluğu kişinin iyilik halinden yoksunluğunu, isteksizliğini ve amaçsızlığını kapsamakla beraber yaşam olaylarının olumsuz şekilde algılandığı negatif bilişsel bir değerlendirmesidir şeklinde tanımlamışlardır. Umutsuzluk ve umutsuzluğa bağıı olarak depresyon gelişen bireyler isteksizlik, güçsüzlük, güdülenme eksikliği, karamsarlık, dikkatini verememe ve yaşamında düzensizlik gibi belirtiler sergileyebilir (Ceyhan, 2004).

Toplumlarda gelişimi, değişimi ve üretimi sağlayan en önemli unsur o toplumun bireyleridir. Toplumun ihtiyaç duyduğu nitelikli bireylerin varlığı ilerlemeyi ve gelişimi de beraberinde getirecektir. İyi bir geleceğin temellerini teknolojik gelişmeleri takip eden, bu gelişmeleri kullanabilen, problem çözebilen, bilgiye nasıl ulaşabileceğini bilen ve yapabilecekleri konusunda kendisine inanan bireyler oluşturmaktadır. Tüm bu üst düzey yeterliliklere sahip olan bir bireyin ileriye yönelik bakış açısı ve gelecekten beklentisi çok önemlidir. Bir bireyin yapabilecekleri ve çevresine katkısı gelecekle ilgili düşüncelerinin pozitiflik düzeyine bağlı olarak artarken umutsuzluk düzeyine bağlı olarak azalmaktadır (Abela ve Seligman, 2000; Poch, Villar ve Caparros, 2004) (Akt. Akçöltekin ve Doğan, 2012).

Üniversite öğrenimi kişisel, sosyal, mesleki ve ekonomik pek çok sorunla başa çıkmayı gerektiren bir geçiş dönemidir. Üniversite öğrencilerinin bu süreçte karşı karşıya gelebildikleri sorunlardan biri de umutsuzluktur. Öğrencilerin üniversite eğitimi sırasında yaşadıkları ekonomik güçlükler, kariyerleriyle ilgili algıladıkları sorunlar ve sosyal ilişki ağları gibi pek çok değişken öğrencilerin umutsuzluk düzeylerini etkileyebilmektedir (Baş ve Kabasakal, 2013). Üniversite eğitimi, kişinin gelecekteki iş ve mesleğinin temel belirleyicisidir. Aileden ayrımanın yarattığı kaygı, yeni bir ortama alışma, barınmada ortaya çıkan sorunlar, maddi sıkıntılar, çevreye uyum sorunu gibi bazı sorunlar gençler üzerinde kaygı, umutsuzluk ve stresi arttırmaktadır. Okul hayatlarının son yıllarında üniversite öğrencilerinde en büyük kaygı kaynağı olarak ise, gelecek endişesi ve bununla bağlantılı olarak bir iş sahibi olma ya da olamama kaygısı, diğer bir ifadeyle "işsizlik kaygısı" başlamakta, umutsuzluk ortaya çıkmaktadır. Ülkemizde özellikle gençler ve üniversite mezunları arasında işsizliğin yaygın olması bu kaygı ve umutsuzluk düzeylerinin daha da artmasına neden olabilmektedir (Dursun ve Aytaç, 2012).

Yaşanan sosyal ve ekonomik sorunlar, üniversiteye giriş, eğitim ve işsizlik sorunları ergenlerin ruhsal gelişimlerini ve ruh sağlığını olumsuz yönde etkilemektedir. Üniversite yıllarında yaşanan sorunlardan birisi de umutsuzluktur (Yalçın ve Açıkgöz, 2014). Ülkemizde sosyal ve ekonomik boyutta 
yaşanan sıkıntılar, eğitim alanındaki eksiklikler ve geleceğe yönelik kaygılar duyuşsal olarak gençlerimizi negatif yönde etkilemekte ve onlarda geleceğe yönelik umutsuzluk duygusunu oluşturmaktadır (Özmen, Dündar, Çetinkaya, Taşkın ve Özmen, 2008).

Bu araştırmada, üniversite öğrencilerinin umutsuzluk düzeylerinin bununla ilişkili olabileceği düşünülen bazı değişkenlere göre incelemesi amaçlanmıştır. Bu kapsamda şu sorulara cevap aranmıştır:

1. Üniversite öğrencilerinin umutsuzluk düzeyi nedir?

2. Üniversite öğrencilerinin umutsuzluk düzeyi ortalamaları cinsiyet, öğrenim görülen fakülte/yüksekokul, anne-baba tutumu, ailenin ortalama aylık geliri ve barınılan yer değişkenlerine göre farklılık göstermekte midir?

Bu araştırmanın sınırlııkları aşağıda verilmiştir.

- Araştırma, 2013-2014 Eğitim-Öğretim Yılı Bahar Yarıyılı́nda Ahi Evran Üniversitesi'ne bağlı 4 yıllık eğitim veren Fakülte/Yüksekokul'ların son sınıflarında okuyan ve anketin yapıldığı zaman diliminde Üniversite'de bulunan öğrencilerle sınırlıdır.

- Araştırma, Beck Umutsuzluk Ölçeği'nde yer alan sorular ve araştırmacı tarafından hazırlanan Kişisel Bilgi Formu'nda yer alan sorular ile sınırıdır.

- Araştırma bulguları öğrencilerin anketlerin uygulandığı zaman diliminde verdikleri yanıtlar ile sınırlıdır.

\section{Yöntem}

Bu bölümde araştırmanın modeli, örneklemi, verilerin toplanması ve verilerin analizi ile ilgili bilgilere yer verilmiştir.

\subsection{Araştırmanın Modeli}

Bu araştırmanın amacı, üniversite öğrencilerinin umutsuzluk düzeylerinin bununla ilişkili olabileceği düşünülen bazı değişkenlere göre incelemesi olduğundan genel tarama modelleri türlerinden ilişkisel tarama modelinin kullanılmasının uygun olacağı düşünülmüştür. Tarama modelleri, geçmişte ya da halen var olan bir durumu var olduğu şekliyle betimlemeyi amaçlayan araştırma yaklaşımlarıdır. Araştırmaya konu olan olay, birey ya da nesne kendi koşulları içinde ve olduğu gibi tanımlanmaya çalışılır. Genel tarama modelleri, çok sayıda elemandan oluşan bir evrende evren hakkında genel bir yargıya varmak amacı ile evrenin tümü ya da ondan alınacak bir grup, örnek ya da örneklem üzerinde yapılan tarama düzenlemeleridir. Genel tarama modelleri içerisinde yer alan ilişkisel tarama modeli ise; iki ya da daha çok sayıdaki değişken arasında birlikte değişim varlığını ve/veya derecesini belirlemeyi amaçlayan araştırma modelidir (Karasar, 2012). 
Kamile ŞANLI KULA | Turan SARAÇ

\subsection{Evren ve Örneklem}

Araştırmanın evreni 2013-2014 Eğitim-Öğretim Yılı Bahar Yarıyılı’nda Ahi Evran Üniversitesi'ne bağlı dört yıllık eğitim veren fakülte ve yüksekokulların dördüncü sınıflarında öğrenim gören 2489 öğrencinin tamamından oluşmaktadır. 2489 öğrencinin tamamına ulaşılmaya çalışılmış ancak 1293 öğrenciye ulaşılabilmiştir. Ulaşılan bu 1293 öğrenciden gönüllük esasına göre Kişisel Bilgi Formu ve Beck Umutsuzluk Ölçeğini cevaplamaları istenmiştir. Ancak analizlere ve amaca uygun olarak dönen anket sayısı 1160 olmuştur. Anketlerin geri dönüş oranı \%89,71 gibi yüksek bir orandır.

Araştırmaya katılan öğrencilerin 770'i (\%66,4) kız, 390' ı (\%33,6) erkek; 73'ü (\%6,3) Beden Eğitimi ve Spor Yüksekokulu (BESYO), 426'sı (\%36,7) Eğitim Fakültesi, 313'ü (\%27,0) Fen Edebiyat Fakültesi (FEF), 33'ü (\%2,9) Fizik Tedavi ve Rehabilitasyon (FTR) Yüksekokulu, 158'i $(\% 13,6)$ iktisadi ve İdari Bilimler Fakültesi (iïBF), 106'sı $(\% 9,1)$ Sağlık Yüksekokulu ve 51'inin $(\% 4,4)$ Ziraat Fakültesinde okuduğu belirlenmiştir.

\subsection{Verilerin Toplanması}

Araştırmanın amacına uygun olarak verilerin toplanması aşamasında araştırmacı tarafından hazırlanan "Kişisel Bilgi Formu" ve Beck, Weissman, Lester, ve Trexler (1974) tarafından geliştirilen "Beck Umutsuzluk Ölçeği" kullanılmıştır. Öğrencilerin cinsiyet, okuduğu fakülte/yüksekokul, annebaba tutumu, ailesinin ortalama aylık geliri ve barındıkları yer ile ilgili sorulara ilişkin veriler araştırmacı tarafından geliştirilen kişisel bilgi formu kullanılarak toplanmıştır. Beck Umutsuzluk Ölçeği Beck ve diğerleri tarafından geliştirilen bireyin geleceğe yönelik karamsarlık düzeyini belirlemeyi amaçlayan bir ölçektir. Beck Umutsuzluk Ölçeği'nin yanıtlanmasında; bireyden kendisine uygun gelen ifadeler için "evet", kendisine uygun olmayan ifadeler için "hayır" şıkkını işaretlemesi istenmektedir. Bu ifadelerden 11 doğru 9 yanlış yanıt anahtarı vardır. Bunlardan 2, 4, 7, 9, 11, 12, 14, 16, 17, 18 ve 20 'nci sorulara verilen yanit evet ise 1 puan $1,3,5,6,8,10,13,15$ ve 19'uncu sorulara verilen yanit hayır ise 1 puan verilmektedir. Bunların aksi verilen cevaplarda ise 0 puan verilmektedir. 1, 6, 13, 15, 19 'uncu önermeler gelecekle ilgili duyguları, 2, 3, 9, 11, 12, 16, 17, 20'nci önermeler motivasyon kaybını, 4, 7, 8, 14, 18'nci önermeler de gelecekle ilgili beklentileri ifade etmektedir. Elde edilen toplam puan "umutsuzluk" puanını oluşturmaktadır. Ölçekten alınabilecek puanlar 0-20 arasında değişmektedir. Alınan puanın yüksek olması bireydeki umutsuzluğun yüksek olduğunu göstermektedir. Beck ve Steer (1988) denekleri yanıtlarına göre dört gurup içinde sınıflandırmış ve 0 ile 3 arası umutsuzluğun tamamen olmadığını, 4 ile 8 arası hafif umutsuzluk olduğunu, 9 ile 14 arası orta seviyede umutsuzluk olduğunu, 15 ile 20 arası ileri derecede umutsuzluk olduğunu bildirmişlerdir (Duman, Taşgın, ve Özdağ, 2009). Beck Umutsuzluk Ölçeği'nin geçerlilik ve güvenirlilik çalışması Seber (1991) ve Durak (1994) tarafından yapılmıştır. Cronbach Alpha iç tutarlıık katsayısı Seber (1991) tarafından 0,86 ve Durak (1994) tarafından 0,85 olarak bulunmuştur (Doğan 2012). Umutsuzluk ölçeğinin, bu çalışmadaki Cronbach Alpha katsayısı ise 0,88 olarak bulunmuştur.

Verilerin toplanması aşamasında öncelikle üniversitenin rektörlüğünden gerekli izinler alınmıştır. Veriler, 2013-2014 Eğitim-Öğretim Yılı Bahar Yarıyılı’nda Ahi Evran Üniversitenin dört yıllık eğitim 
veren fakülte/yüksekokullarına devam eden 1160 öğrenciden ders saatlerinde bizzat araştırmacıların kendisi tarafından toplanmıştır.

\subsection{Verilerin Analizi}

Veriler çözümlenirken ilk önce kişisel bilgilere göre çalışma grubunun frekans ve yüzde değerleri incelenmiştir. Öğrencilerin umutsuzluk puanları ortalaması alınarak grubun genel umutsuzluk düzeyi değerlendirilmiştir. İkinci aşamada cinsiyete göre umutsuzluk düzeyi ortalamaları arasında farklılık olup olmadığını belirlemek için bağımsız örneklem t-testi kullanılmıştır. Fakülte/yüksekokul, annebaba tutumu, ailenin ortalama aylık geliri ve barınılan yer değişkenleri bakımından umutsuzluk düzeyi ortalamaları arasında farklılık olup olmadığını belirlemek amacıyla tek yönlü varyans analizi (ANOVA) uygulanmıştır. ANOVA sonucuna göre uygulanacak çoklu karşılaştırma testinin seçiminde varyansların ve örneklem büyüklüklerinin eşit olup olmama durumu oldukça etkili olabilmektedir. Uygun olmayan çoklu karşılaştırma testinin seçimi araştırmada bir yanlılık oluşturarak hipotez kararları için I. ve II. tip hata risklerine yol açabilmektedir. Veri setinin özelliği ve karşılaştırma yapılacak olan grup sayısı hangi testin kullanılacağını belirlemede önem taşımaktadır (Kayri, 2009). Çoklu karşılaştırmalardan önce yapılan varyansların homojenliği testinde varyansların homojen olmadığı belirlenmiştir. ANOVA sonucu belirlenen anlamlı farklılıkların hangi düzeylerden kaynaklandığını belirlemek için bu duruma uygun olarak Games-Howell testi kullanılmıştır.

\section{Bulgular}

Öğrencilerin umutsuzluk düzeyine ilişkin analiz sonuçları Tablo 1'de verilmiştir.

Tablo 1. Öğrencilerin Genel Umutsuzluk Düzeyleri

\begin{tabular}{cccccc}
\hline \hline & $n$ & Minimum & Maksimum & $\bar{x}$ & $s s$ \\
\hline Umutsuzluk Puanı & 1160 & 0 & 20 & 4,84 & 4,53 \\
\hline
\end{tabular}

Tablo 1'den öğrencilerin umutsuzluk puanları ortalamasının 20 üzerinden $\bar{x}=4,84$ olduğu görülmektedir. Bu sonuca göre üniversite öğrencilerinin geleceğe yönelik umutsuzluk düzeyinin hafif olduğunu ve gelecekle ilgili umutlarının çok olumsuz olmadığını söyleyebiliriz. Bununla birlikte, 1160 öğrencinin 617'sinde (\%53) umutsuzluğun olmadığı, 306'sında (\%26) hafif düzeyde, 181'inde (\%16) orta düzeyde ve 56 'sında (\%5) ileri düzeyde umutsuzluk olduğu tespit edilmiştir. Öğrencilerin genel umutsuzluk puanı ortalaması düşük olmakla birlikte $\% 16$ 'sı orta düzeyde $\% 5$ 'i ise ileri düzeyde umutsuzluk yaşadıklarını belirtmişlerdir. Öğrencilerin 237'si (\%21) orta ve daha üst düzeyde umutsuzluk yaşamaktadırlar.

Öğrencilerin cinsiyetlerine göre umutsuzluk puanları ortalamaları arasında farklılık olup olmadığını belirlemek için uygulanan bağımsız örneklem t-testi sonuçları Tablo 2'de verilmiştir. 
Tablo 2. Öğrencilerin Cinsiyetlerine Göre Umutsuzluk Puanlarına İlişkin Bağımsız Örneklem tTesti Sonuçları

\begin{tabular}{ccccccc}
\hline \hline Cinsiyet & $n$ & $\bar{x}$ & ss & $t$ & sd & $p$ \\
\hline KIz & 770 & 4,51 & 4,40 & $-3,498$ & \multirow{2}{*}{737,023} & \multirow{2}{*}{0,01} \\
Erkek & 390 & 5,51 & 4,71 & & \\
\hline
\end{tabular}

Tablo 2 incelendiğinde kız öğrencilerin umutsuzluk puanları ortalamasının ( $\bar{x}=4,51)$ erkek öğrencilerin umutsuzluk puanları ortalamasından ( $\bar{x}=5,51)$ daha düşük olduğu görülmektedir. Kız ve erkek öğrencilerin umutsuzluk puanları ortalamaları arasındaki bu farkın istatistiksel olarak anlamlı olduğu belirlenmiştir $(p<0,05)$. Böylece cinsiyetin öğrencilerin umutsuzluk düzeyleri üzerinde etkili olduğunu söyleyebiliriz. Bu sonuç, erkek öğrencilerin umutsuzluk düzeylerinin kızlardan daha fazla olduğunu göstermektedir.

Tablo 3'te öğrencilerin öğrenim gördükleri fakülte ve yüksekokullara göre umutsuzluk puanlarına ilişkin özet istatistik değerleri verilmiştir.

Tablo 3. Öğrencilerin Öğrenim Gördükleri Fakülte ve Yüksekokullara Göre Umutsuzluk Puanlarına Illişkin Özet İstatistik Sonuçları

\begin{tabular}{lccc}
\hline \hline \multicolumn{1}{c}{ Fakülte/Yüksekokul } & $n$ & $\bar{x}$ & ss \\
\hline BESYO & 73 & 4,52 & 4,34 \\
Eğitim Fakültesi & 426 & 4,26 & 4,29 \\
FEF & 313 & 6,30 & 4,94 \\
FTR Yüksekokulu & 33 & 3,90 & 4,00 \\
iiBF & 158 & 5,47 & 4,59 \\
Sağlık Yüksekokulu & 106 & 3,10 & 3,13 \\
Ziraat Fakültesi & 51 & 3,52 & 3,93 \\
\hline
\end{tabular}

En yüksek umutsuzluk puanı ortalamasına sahip fakülte FEF ( $\bar{x}=6,30$ ) olurken, Sağlık Yüksekokulunda okuyan öğrencilerin umutsuzluk puanları ortalaması ise $(\bar{x}=3,10)$ en düşük çıkmıştır.

Öğrencilerin öğrenim gördükleri fakülte ve yüksekokullara göre umutsuzluk puanları ortalamaları arasındaki farklılı̆̆ın istatistiksel olarak anlamlı olup olmadığı ANOVA ile test edilmiştir ve Tablo 4'te verilmiştir. 
Tablo 4. Öğrencilerin Öğrenim Gördükleri Fakülte ve Yüksekokullara Göre Umutsuzluk Puanlarına Iliş̧kin ANOVA Sonuçları

\begin{tabular}{lccccc}
\hline \hline \multicolumn{1}{c}{ Varyans Kaynağı } & $\begin{array}{c}\text { Kareler Top- } \\
\text { lamı }\end{array}$ & sd & $\begin{array}{c}\text { Kareler Orta- } \\
\text { laması }\end{array}$ & $F$ & $p$ \\
\hline Gruplar Arası & 1321,973 & 6 & 220,329 & 11,290 & 0,01 \\
Gruplar İçi & 22502,019 & 1153 & 19,516 & & \\
Toplam & 23823,992 & 1159 & & & \\
\hline
\end{tabular}

Tablodan öğrencilerin okudukları fakülte ve yüksekokullara göre umutsuzluk puanları ortalamaları arasında istatistiksel açıdan anlamlı bir farklılık olduğu görülmektedir $(F(6,1153)=11,290$, $p<0,05)$. Bu farkın hangi fakülte ve yüksekokullar arasında olduğunu belirlemek için yapılan GamesHowell testinden elde edilen sonuçlar Tablo 5'de verilmiştir.

Tablo 5 incelendiğinde BESYO'da okuyan öğrencilerin umutsuzluk puanları ortalamasının FEF'te okuyan öğrencilerin umutsuzluk puanları ortalamasına göre istatistiksel olarak anlamlı derecede düşük olduğu görülmektedir. Eğitim Fakültesinde okuyan öğrencilerin umutsuzluk puanları ortalamasının ise FEF'te okuyan öğrencilerin umutsuzluk puanları ortalamasına göre istatistiksel olarak anlamlı derecede düşük; Sağlık Yüksekokulunda okuyan öğrencilerin umutsuzluk puanları ortalamasına göre anlamlı derecede yüksektir. FEF'te okuyan öğrencilerin umutsuzluk puanları ortalaması; FTR Yüksekokulu, Sağlık Yüksekokulu ve Ziraat Fakültesinde okuyan öğrencilerin umutsuzluk puanları ortalamalarına göre istatistiksel olarak anlamlı derecede yüksek bulunmuştur. iïBF'de okuyan öğrencilerin umutsuzluk puanları ortalaması Sağlık Yüksekokulunda okuyan öğrencilerin umutsuzluk puanları ortalamasına göre istatistiksel olarak anlamlı derecede yüksektir.

Tablo 5. Öğrencilerin Öğrenim Gördükleri Fakülte ve Yüksekokullara Göre Umutsuzluk Puanlarına Illişkin Games-Howell Testi Sonuçları

\begin{tabular}{llccc}
\hline \hline & Gruplar & $\begin{array}{c}\text { Ortalama } \\
\text { Fark }\end{array}$ & $\begin{array}{c}\text { Standart } \\
\text { Hata }\end{array}$ & $p$ \\
\hline BESYO & Eğitim Fakültesi & 0,25764 & 0,55005 & 0,999 \\
& FEF & $-1,78616$ & 0,58091 & $0,041^{*}$ \\
& FTR Yüksekokulu & 0,61146 & 0,86297 & 0,992 \\
& iiBF & $-0,95414$ & 0,62695 & 0,731 \\
& Sağlık Yüksekokulu & 1,41677 & 0,59320 & 0,212 \\
Eğitim Fakültesi & Ziraat Fakültesi & 0,99114 & 0,75032 & 0,841 \\
& BESYO & $-0,25764$ & 0,55005 & 0,999 \\
& FEF & $-2,04380$ & 0,34880 & $0,000^{*}$ \\
& FTR Yüksekokulu & 0,35382 & 0,72727 & 0,999 \\
& iiBF & $-1,21177$ & 0,42104 & 0,065 \\
FEF & Sağlık Yüksekokulu & 1,15914 & 0,36891 & $0,031^{*}$ \\
& Ziraat Fakültesi & 0,73350 & 0,58923 & 0,874 \\
& BESYO & 1,78616 & 0,58091 & $0,041^{*}$ \\
\hline
\end{tabular}


Kamile ŞANLI KULA | Turan SARAÇ

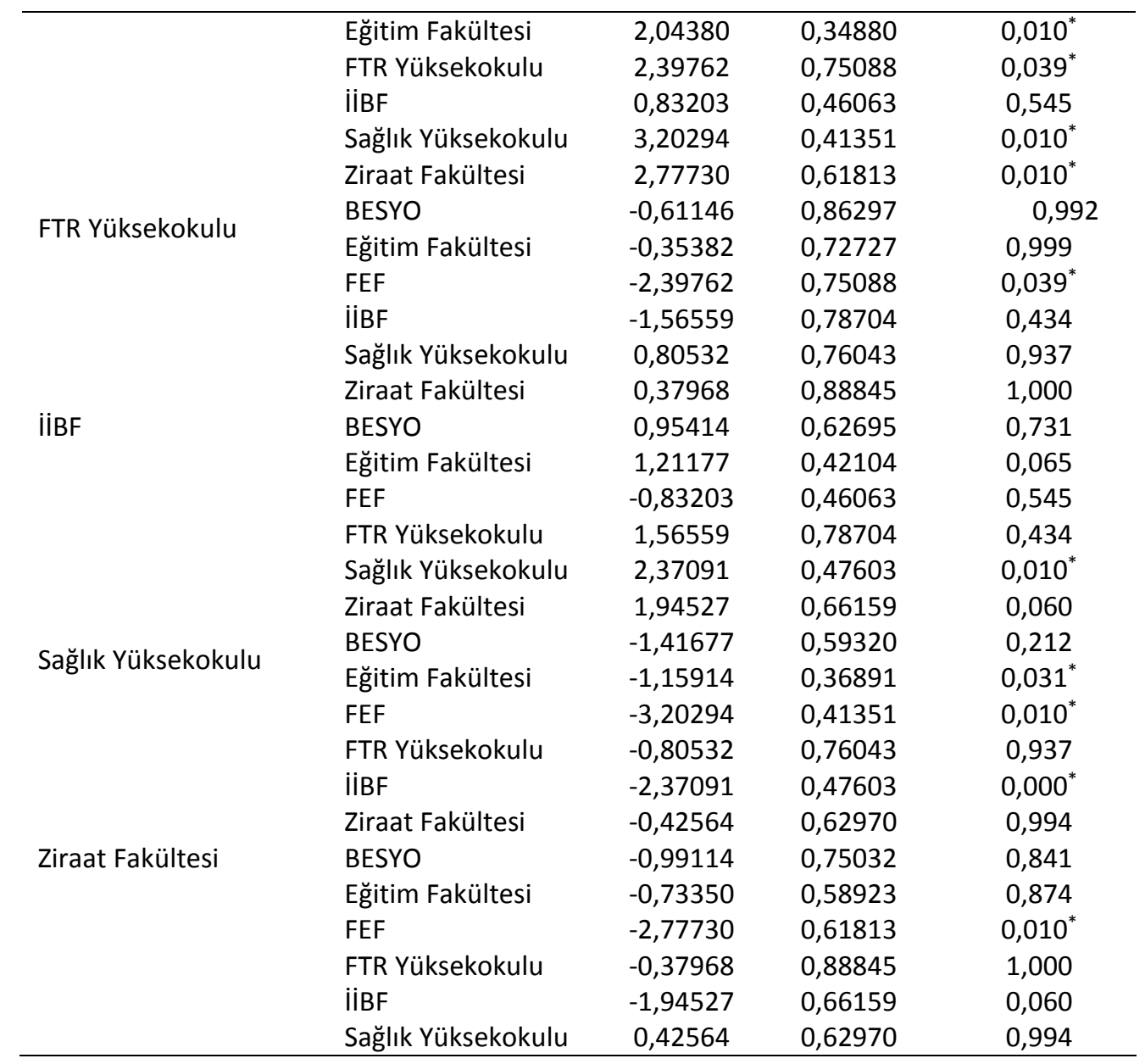

${ }^{*} \mathrm{p}<0,05$

Öğrencilerin anne-baba tutumlarına göre Beck Umutsuzluk Ölçeği’nden aldıkları puanlara ilişkin özet istatistik değerleri Tablo 6'da verilmiştir. 
Tablo 6. Öğrencilerin Anne-Baba Tutumlarına Göre Umutsuzluk Puanlarına İlişkin Özet İstatistik Sonuçları

\begin{tabular}{lccc}
\hline \hline \multicolumn{1}{c}{ Anne-Baba Tutumu } & $n$ & $\bar{x}$ & ss \\
\hline ilgisiz & 37 & 7,43 & 5,80 \\
Otoriter & 230 & 5,37 & 4,87 \\
Demokrat & 893 & 4,60 & 4,33 \\
\hline
\end{tabular}

Her grup için umutsuzluk puanları ortalaması hafif düzey olarak kabul edilen 4-8 aralığında bulunmuştur. Ailesinin ilgisiz olduğunu ifade eden öğrencilerin umutsuzluk puanları ortalamasının en yüksek, ailesinin demokrat olduğunu ifade eden öğrencilerin umutsuzluk puanları ortalamasının en düşük olduğu tespit edilmiştir.

Anne-baba tutumlarına göre öğrencilerin umutsuzluk düzeyleri arasında farklılık olup olmadığını belirlemek için yapılan ANOVA testi sonuçları Tablo 7'deki gibidir.

Tablo 7. Öğrencilerin Anne-Baba Tutumlarına Göre Umutsuzluk Puanlarına ilişkin ANOVA So-

\begin{tabular}{lccccc}
\multicolumn{7}{c}{ nuçları } \\
\hline \hline \multicolumn{1}{c}{ Varyans Kaynağı } & $\begin{array}{c}\text { Kareler Top- } \\
\text { lamı }\end{array}$ & sd & $\begin{array}{c}\text { Kareler Ortala- } \\
\text { ması }\end{array}$ & $F$ & $p$ \\
\hline Gruplar Arası & 365,151 & 2 & 182,576 & 9,005 & 0,01 \\
Gruplar İçi & 23458,841 & 1157 & 20,276 & & \\
Toplam & 23823,992 & 1159 & & & \\
\hline
\end{tabular}

Tablo 7 incelendiğinde öğrencilerin anne-baba tutumlarına göre umutsuzluk düzeyleri arasında istatistiksel olarak anlamlı farklılık olduğu görülmüştür $(F(2,1157)=9,005, p<0,05)$. Bu farkın hangi gruplar arasında olduğunu belirlemek için yapılan Games-Howell testi sonuçları Tablo 8' de verilmiştir.

Tablo 8. Öğrencilerin Anne-Baba Tutumlarına Göre Umutsuzluk Puanlarına ilişkin GamesHowell Testi Sonuçları

\begin{tabular}{llccc}
\hline \hline \multicolumn{2}{c}{ Gruplar } & Ortalama Fark & Standart Hata & $\mathrm{p}$ \\
\hline \multirow{2}{*}{ İlgisiz } & Otoriter & 2,05417 & 1,00778 & 0,115 \\
& Demokrat & 2,82885 & 0,96608 & $0,016^{*}$ \\
\multirow{3}{*}{ Demoriter } & ilgisiz & $-2,05417$ & 1,00778 & 0,115 \\
& Demokrat & 0,77468 & 0,35283 & 0,073 \\
& ilgisiz & $-2,82885$ & 0,96608 & $0,016^{*}$ \\
& Otoriter & $-0,77468$ & 0,35283 & 0,073 \\
\hline
\end{tabular}

${ }^{*} \mathrm{p}<0,05$

Anne-babasının ilgisiz olduğunu ifade eden öğrencilerin umutsuzluk puanı ortalaması ile annebabasının demokrat olduğunu ifade eden öğrencilerin umutsuzluk puanı ortalaması arasında istatis- 
tiksel açıdan anlamlı bir farklılık vardır. Anne-babasının ilgisiz olduğunu ifade eden öğrencilerin umutsuzluk puanı ortalaması, anne-babasını demokrat olarak tanımlayan öğrencilerin umutsuzluk puanı ortalamasına göre daha yüksek bulunmuştur.

Öğrencilerin ailelerinin ortalama aylık gelirlerine göre umutsuzluk düzeylerine ilişkin özet istatistikleri Tablo 9'daki gibidir.

Çalışma Genel Müdürlüğü İstatistik ve Yetki Otomasyon Dairesi'nin verilerine göre 2013 yılının ikinci altı ayı için asgari ücret 1.021,50 TL net 803,68TL'dir. Türk-iş'in yapmış olduğu bir araştırmanın sonuçlarına göre 2013 yılı Ekim ayında 4 kişilik bir ailenin yoksulluk sınıı 3.466,65TL Aralık ayı için ise 3.523,09TL'dir. Çalışmada öğrencilerin ailelerinin ortalama aylık geliri belirlenirken asgari ücret ve yoksulluk sınırı kullanılmıştır.

Tablo 9. Öğrencilerin Ailelerinin Ortalama Aylık Gelirine Göre Umutsuzluk Puanlarına Illişkin Özet İstatistik Sonuçları

\begin{tabular}{lccc}
\hline \multicolumn{1}{c}{ Ailenin Ortalama Aylık Geliri } & $n$ & $\bar{x}$ & ss \\
\hline 800 TL'den az & 170 & 5,88 & 5,29 \\
800-3.499 TL & 895 & 4,66 & 4,39 \\
3.500 TL + & 95 & 4,68 & 4,14 \\
\hline
\end{tabular}

Tablo 9 incelendiğinde ailesinin ortalama aylık geliri 800 TL den az olan öğrencilerin umutsuzluk puanları ortalaması $\bar{x}=5,88$, ailesinin ortalama aylık geliri 800-3.499 TL aralığında olan öğrencilerin umutsuzluk puanları ortalaması $\bar{x}=4,66$, ailesinin ortalama aylık geliri 3.500 TL ve üzeri olan öğrencilerin umutsuzluk puanları ortalamasının $\bar{x}=4,68$ olduğu görülmektedir. Tüm gruplar için umutsuzluk puanları ortalamaları hafif düzey olarak kabul edilen 4-8 aralığında bulunmuştur.

Öğrencilerin ailelerinin ortalama aylık gelirlerine göre umutsuzluk puanları ortalamaları arasındaki farkın istatistiksel açıdan anlamlı olup olmadığı ANOVA ile analiz edilmiş ve Tablo 10 'da verilmiştir.

Tablo 10. Öğrencilerin Ailelerinin Ortalama Aylık Gelirine Göre Umutsuzluk Puanlarına Illişkin ANOVA Sonuçları

\begin{tabular}{lccccc}
\hline \hline Varyans Kaynağı & Kareler Toplamı & sd & $\begin{array}{c}\text { Kareler Or- } \\
\text { talaması }\end{array}$ & $F$ & $p$ \\
\hline Gruplar Arası & 215,812 & 2 & 107,906 & 5,288 & 0,005 \\
Gruplar İçi & 23608,180 & 1157 & 20,405 & & \\
Toplam & 23823,992 & 1159 & & & \\
\hline
\end{tabular}

Tablo 10 incelendiğinde öğrencilerin ailelerinin ortalama aylık gelirine göre umutsuzluk düzeyleri arasında istatistiksel olarak anlamlı farklılık olduğu görülmüştür $(F(2,1157)=5,288, p<0,05)$. Bu farkın hangi gruplar arasında olduğunu belirlemek için yapılan Games-Howell testi sonuçları Tablo 11 'de verilmiştir. 
Tablo 11. Öğrencilerin Ailelerinin Ortalama Aylık Gelirine Göre Umutsuzluk Puanlarına Illişkin Games-Howell Testi Sonuçları

\begin{tabular}{llccc}
\hline \hline & \multicolumn{1}{c}{ Gruplar } & Ortalama Fark & $\begin{array}{c}\text { Standart } \\
\text { Hata }\end{array}$ & $p$ \\
\hline 800 TL'den az & 800-3.499 TL & 1,22120 & 0,43164 & $0,014^{*}$ \\
& 3.500 TL + & 1,20402 & 0,58782 & 0,103 \\
800-3.499 TL & 800 TL'den az & $-1,22120$ & 0,43164 & $0,014^{*}$ \\
& 3.500 TL+ & $-0,01717$ & 0,44986 & 0,999 \\
3500 TL+ & 800 TL'den az & $-1,20402$ & 0,58782 & 0,103 \\
& 800-3.499 TL & 0,01717 & 0,44986 & 0,999 \\
\hline
\end{tabular}

${ }^{*} \mathrm{p}<0,05$

Ailesinin ortalama aylık geliri 800 TL'den az olan öğrencilerin umutsuzluk puanları ortalaması ile ailesinin ortalama aylık geliri 800-3.499 TL aralığında olan öğrencilerin umutsuzluk puanları ortalaması arasında istatistiksel açıdan anlamlı bir farklııık vardır. Tablodan ailesinin ortalama aylık geliri 800 TL'den az olan öğrencilerin umutsuzluk puanları ortalamasının, ailesinin ortalama aylık geliri 800-3.499 TL aralığında olan öğrencilerin umutsuzluk puanları ortalamasından daha yüksek olduğu görülmektedir.

Tablo 12'de öğrencilerin barındıkları yerlere göre Beck Umutsuzluk Ölçeği'nden aldıkları puanlara ilişkin özet istatistikler yer almaktadır.

Tablo 12. Öğrencilerin Barındıkları Yerlere Göre Umutsuzluk Puanlarına İlişkin Özet İstatistik Sonuçları

\begin{tabular}{|c|c|c|c|}
\hline Barınılan Yer & $n$ & $\bar{x}$ & ss \\
\hline Devlet Yurdu & 272 & 4,84 & 4,49 \\
\hline Özel Yurt & 104 & 4,97 & 4,30 \\
\hline Apart & 103 & 4,62 & 4,41 \\
\hline Ev & 681 & 4,86 & 4,60 \\
\hline
\end{tabular}

Apartta kalan öğrencilerin umutsuzluk puanları ortalamasının en düşük, özel yurtta kalan öğrencilerin umutsuzluk puanları ortalamasının en yüksek olduğu tespit edilmiştir. Bütün grupların umutsuzluk puanları ortalamaları hafif düzey olarak belirtilen 4-8 aralığında bulunmuştur.

Öğrencilerin barındıkları yerlere göre umutsuzluk puanları ortalamaları arasında istatistiksel açıdan anlamlı farklıık olup olmadığı ANOVA ile test edilmiştir. Analiz sonuçları Tablo 13'te verilmiştir. 
Kamile ŞANLI KULA | Turan SARAÇ

Tablo 13. Öğrencilerin Barındıkları Yerlere Göre Umutsuzluk Puanlarına Illişkin ANOVA

\begin{tabular}{lccccc}
\hline \hline Varyans Kaynağı & Kareler Toplamı & sd & $\begin{array}{c}\text { Kareler Or- } \\
\text { talaması }\end{array}$ & $F$ & $p$ \\
\hline Gruplar Arası & 7,072 & 3 & 2,357 & 0,114 & 0,952 \\
Gruplar İçi & 23816,920 & 1156 & 20,603 & & \\
Toplam & 23823,992 & 1159 & & & \\
\hline
\end{tabular}

Tablo incelendiğinde öğrencilerin barındıkları yerlere göre umutsuzluk puanları ortalamaları arasında istatistiksel olarak anlamlı farklılık olmadığı görülmüştür $(F(3,1156)=0,114, p>0,05)$.

\section{Sonuç, Tartışma ve Öneriler}

Bu araştırmada, Ahi Evran Üniversitenin dört yıllık eğitim veren fakülte/yüksekokullarının son sınıflarında öğrenim gören öğrencilerin umutsuzluk düzeylerinin bununla ilişkili olabileceği düşünülen bazı değişkenlere göre incelenmesi amaçlanmıştır.

Araştırma sonucuna göre üniversite son sınıf öğrencilerinin genel umutsuzluk düzeyi hafif olmakla birlikte, ileri düzeyde umutsuzluk yaşayan öğrencilerin olduğu belirlenmiştir. \%16'sı orta düzeyde $\% 5$ 'i ise ileri düzeyde umutsuzluk yaşadıklarını ifade etmişlerdir. Üniversite son sınıf öğrencilerinin umutsuzluk düzeylerinin cinsiyet, okudukları fakülte ve yüksekokul, anne-baba tutumu ve ailelerinin ortalama aylık geliri değişkenlerine göre farklıık gösterdiği, barınılan yer değişkenine göre ise farklılık olmadığı belirlenmiştir.

Bu araştırmaya göre, öğrencilerin cinsiyetlerine göre umutsuzluk puanları ortalamalarının farklı olduğu görülmüştür. Erkek öğrencilerin umutsuzluk düzeyinin kız öğrencilerinkine göre istatistiksel olarak anlamlı derecede daha yüksek olduğu belirlenmiştir. Umutsuzluk düzeyleri üzerinde cinsiyet faktörünün etkisine ilişkin yapılan çalışmalarda farklı sonuçlar elde edildiği görülmektedir. Bazı araştırmalarda bu çalışmada olduğu gibi erkek öğrencilerin umutsuzluk düzeyleri kı öğrencilere göre anlamlı derecede yüksek bulunurken (Baş ve Kabasakal, 2013; Ceyhan, 2004; C. Şahin, 2009; Üstün vd., 2014; Çelikel ve Erkorkmaz, 2008), bazı araştırmalarda ise kız öğrencilerin umutsuzluk düzeyleri erkek öğrencilere göre anlamlı derecede daha yüksek bulunmuştur (Üngören ve Ehtiyar, 2009). Çaıışmaların bazılarında ise cinsiyet değişkeni ile umutsuzluk düzeyleri arasında anlamlı bir farklııı olmadığı sonucuna ulaşımıştır (Aras, 2011; Dereli ve Kabataş, 2009; Gençay ve Gençay, 2011; A. Şahin, 2002; Yenilmez, 2010; Tümkaya, Çelik ve Aybek, 2011; Akçöltekin ve Doğan, 2012). Bu araştırmada erkek öğrencilerin umutsuzluklarının kız öğrencilere göre daha yüksek olmasının sebebi, son yıllarda bu görüş değişmekle birlikte, Çelikel ve Erkorkmaz (2008)'ın da ifade ettiği gibi, toplumumuzda erkeğe yüklenen rol gereği, mezun olduktan sonra hemen iş bulmak ve ailenin geçimini sağlamak zorunda olduklarını düşünmeleri olabilir.

Farklı fakülte ve yüksekokullarda öğrenim gören öğrencilerin umutsuzluk düzeyleri arasında istatistiksel olarak anlamlı farklılıklar bulunmuştur. FEF'te okuyan öğrencilerin umutsuzluk düzeyi ortalaması en yüksek, Sağlık Yüksekokulunda okuyan öğrencilerin ise en düşük bulunmuştur. Derebaşı 
(1996) Fen ve Uygulamalı bilimlerdeki öğrencilerin umutsuzluk düzeylerinin fazla, en düşük umutsuzluk düzeyinin ise Güzel Sanatlar öğrencilerinde olduğunu belirtmiştir. Üstün ve diğerleri (2014) Eğitim Fakültesi ve Sağlık Yüksekokulunda okuyan öğrenciler için yaptıkları karşılaştırmada Eğitim Fakültesinde okuyan öğrencilerin umutsuzluk puanlarının Sağlık Yüksekokulunda okuyan öğrencilere göre anlamlı derecede yüksek olduğunu bulmuşlardır. Çelikel ve Erkorkmaz (2008) araştırmalarında umutsuzluk düzeyi en düşük Eğitim fakültesi öğrencileri iken en yüksek Fen Edebiyat Fakültesi öğrencileri olarak bulmuşlardır. Araştırma ile elde edilen sonuç Derebaşı (1996) ve Çelikel ve Erkorkmaz (2008)'ın çalışmaları ile uyumludur. Fen Edebiyat Fakültesi öğrencilerinin çalışma alanlarının sınırlı olması nedeniyle mezun olduktan sonra iş bulamama düşüncesiyle daha umutsuz oldukları söylenebilir.

Anne-baba tutumuma göre öğrencilerin umutsuzluk düzeyleri arasında anlamlı farklııı olduğu tespit edilmiştir. Anne-babasının ilgisiz olduğunu ifade eden öğrencilerin umutsuzluk düzeyleri annebabasının demokrat olduğunu belirten öğrencilerin umutsuzluk düzeylerine göre daha yüksek bulunmuştur. Tümkaya vd. (2011) lise öğrencileri ile ilgili yaptıkları çalışmada anne-baba tutumunu otoriter-koruyucu ve demokratik alt boyutlarında incelemişlerdir. Anne baba tutumuna göre umutsuzluk düzeylerinin farklılaşmadığını belirtmişlerdir. Araştırmada anne-babasının tutumunun ilgisiz olduğunu belirten öğrencilerin umutsuzluk düzeylerinin daha yüksek çıkmasının sebebi gelecekte karşılaşabilecekleri sorunlarla yalnız baş edeceklerini düşünmelerinden dolayı olabilir.

Öğrencilerin ailelerinin ortalama aylık geliri ile umutsuzluk düzeyleri arasında anlamlı farklılık olduğu belirlenmiştir. C. Şahin (2009), Tekin ve Filiz (2008)'in çalışmalarında elde edilen sonuçla araştırmanın sonucu uyumludur. Bazı araştırmalarda ise gelir seviyesinin umutsuzluk ve depresyon üzerinde farklılık yaratan bir etken olmadığı sonucu elde edilmiştir (Kazdin, Rodgers ve Colbuls, 1986; Mangır, Aral ve Aksoy, 1990; Tümkaya vd., 2011). Ailelerinin ortalama aylık geliri düşük olan öğrencilerin umutsuzluk düzeyi ortalamasının diğerlerine göre yüksek olmasının sebebi C. Şahin (2009)'in de belirtiği gibi, gelir düzeyinin gelecek güvencesi açısından önemli olması ve düşük gelir düzeyinin umutsuzluğu arttırdığını söyleyebiliriz.

Araştırmada barınılan yer faktörünün öğrencilerin umutsuzluk düzeylerinde farklılık yaratan bir etken olmadığı görülmüştür. Buna karşılık C. Şahin (2009), Üstün vd., (2014) kalınan yer bakımından umutsuzluk puanları arasında istatistiksel olarak anlamlı farklılık olduğunu tespit etmişlerdir.

Üniversitenin son sınıfı öğrenciliğin sonlandığı ve hemen sonrasında iş yaşamının başlayacağı bir aşamadır. Bu aşamada her fakülte ve yüksekokula göre alanında uzman kişilerce öğrencilere okudukları fakülte/yüksekokul'un iş olanakları, mezun olduktan sonra iş bulmak için yapmaları gerekenler vb. gibi konularda seminerler verilebilir, mezunlar ile öğrenciler buluşturularak mezun olduktan sonra karşılaşılan problemler belirlenip çözüm yolları araştırılabilir. Böylece bu sürecin öğrencilerce daha kolay atlatmaları sağlanabilir.

\section{Teşekkür}

Bu çalışma Ahi Evran Üniversitesi tarafından PYO-FEN.4003.13.001 proje numarası ile desteklenmiştir. 
Kamile ŞANLI KULA | Turan SARAÇ

\section{Kaynaklar}

Akçöltekin, A. ve Doğan, S. (2012). Sınıf Öğretmenlerinin Umutsuzluk Düzeylerinin Farklı Değişkenler Açısından İncelenmesi: Ardahan İli Örneği. The Journal of Academic Social Science Studies, 5(7), 49-59.

Aras, A. (2011). Müzik Bölümü Lisans Öğrencilerinin Umutsuzluk Düzeylerinin Belirlenmesi: Hacettepe Üniversitesi Ankara Devlet Konservatuarı Örneği. Gazi Üniversitesi Gazi Eğitim Fakültesi Dergisi, 31(2), 509-524.

Baş, A. U. ve Kabasakal, Z. (2013). Öğretmen Adaylarında Umutsuzluk ve Algılanan Sosyal Destek. Eğitim ve Öğretim Araştırmaları Dergisi. Journal of Research in Education and Teaching, 2(1), 19-26.

Beck, A. T., Weissman, A., Lester, D. and Trexler, L. (1974). The Measurement of Pessimism: The Hopelessness Scale. Journal of Consulting and Clinical Psychology, 42, 861-865.

Beck, A. T. and Steer, R. A. (1988). Manual for the Beck Hopelessness Scale, Psychological Corporation, San Antonio TX.

Ceyhan, A. A. (2004). Ortaöğretim Alan Öğretmenliği Tezsiz Yüksek Lisans Programına Devam Eden Öğretmen Adaylarının Umutsuzluk Düzeylerinin İncelenmesi. Anadolu Üniversitesi Sosyal Bilimler Dergisi, 1, 91-101.

Çelikel, F.Ç. ve Erkorkmaz, Ü. (2008). Üniversite Öğrencilerinde Depresif Belirtiler ve Umutsuzluk Düzeyleri ile ilişkili Etmenler. Nöropsikiyatri Arşivi, 45, 122-129.

Derebaşı, I. (1996). Beck Umutsuzluk Ölçeğinin Ege Üniversitesi Öğrencileri Üzerinde Geliştirilmesi. Yayımlanmamış yüksek lisans tezi, Ege Üniversitesi Sosyal Bilimler Enstitüsü, İzmir.

Dereli, F. ve Kabataş, S. (2009). Sağlık Yüksekokulu Son Sınıf Öğrencilerinin İş Bulma Endişeleri ve Umutsuzluk Düzeylerinin Belirlenmesi. Yeni Tıp Dergisi, 26, 31-36.

Dilbaz, N. ve Seber, G. (1993). Umutsuzluk Kavramı: Depresyon ve İntiharda Önemi. Kriz Dergisi, 1(3), 134-138.

Doğan, P. (2012). Resim Öğretmeni Adaylarının Umutsuzluk Düzeylerinin İncelenmesi. Atatürk Eğitim Fakültesi Eğitim Bilimleri Dergisi, 36, 115-127.

Duman, S., Taşgın, Ö. ve Özdağ, S. (2009). Beden Eğitimi ve Spor Yüksekokulu Spor Yöneticiliği Bölümünde Okuyan Öğrencilerin Umutsuzluk Düzeylerinin İncelenmesi. Selçuk Üniversitesi Beden Eğitimi ve Spor Bilim Dergisi, 11 (3), 27-32. 
Durak, A. (1994). Beck Umutsuzluk Ölçeğinin Geçerlik ve Güvenirlik Çalışması. Türk Psikoloji Dergisi, $9(31), 1-11$.

Dursun, S. ve Aytaç, S. (2012). Üniversite Öğrencilerinin İşgücü Piyasasına Yönelik Beklentileri ve İş Deneyimleri ile Umutsuzluk ve Kaygı Düzeyleri Arasındaki Iliş̧i Üzerine Bir Araştırma. Celal Bayar Üniversitesi Sosyal Bilimler Dergisi, 10(1), 373-388.

Gençay, S. ve Gençay, Ö. A. (2011). A Comparision of the Life Satisfaction and Hopelessness Levels of Teacher Candidates In Turkey. Educational Research and Reviews, 6(2), 182-186.

Karasar, N. (2012). Bilimsel araştırma yöntemi. Ankara: Nobel Yayınclık.

Kayri, M. (2009). Araştırmalarda Gruplar Arası Farkın Belirlenmesine Yönelik Çoklu Karşılaştırma (Post-Hoc) Teknikleri. Fırat Üniversitesi Sosyal Bilimler Dergisi, 19(1), 51-64.

Kazdin, A. E., Rodgers, A. and Colbuls, D. (1986). The Hopelessness Scale for Children: Psychometric Characteristics and Concurrent Validity. Journal of Consulting and Clinical Psychology, 54(2), 241-245.

Mangır, M., Aral, N. ve Aksoy, A. (1990). Ankara Üniversitesi Ziraat Fakültesi Ev Ekonomisi Yüksek Okulu ile Tarımsal Mekanizasyon Bölümü Birinci Sını Öğrencilerinin Depresyon Durumlarını Etkileyen Bazı Etmenler Üzerinde Bir Araştırma. Ankara: Ankara Üniversitesi Ziraat Fakültesi Yayınları, Bilimsel Araştırma ve İncelemeler.

Özmen, D., Dündar, P.E., Çetinkaya, A. Ç., Taşkın, E. O. ve Özmen, E. (2008). Lise Öğrencilerinde Umutsuzluk ve Umutsuzluk Düzeyini Etkileyen Etkenler. Anadolu Psikiyatri Dergisi, 9 (1), 8-15.

Seber, G. (1991). Beck Umutsuzluk Ölçeğinin Geçerlik ve Güvenirliği Üzerine Bir Çalışma. Yayımlanmamış doçentlik tezi, Anadolu Üniversitesi Sağlık Bilimleri Enstitüsü, Eskişehir.

Şahin, A. (2002). Illahiyat fakültesi öğrencilerinin umutsuzluk düzeyleri üzerine bir araştırma. Selçuk Üniversitesi Ilahiyat Fakültesi Dergisi, 13, 143-157.

Şahin, C. (2009). Eğitim Fakültesinde Öğrenim Gören Öğrencilerin Umutsuzluk Düzeyleri. Selçuk Üniversitesi Ahmet Keleşoğlu Eğitim Fakültesi Dergisi, 27, 271-286.

Saraç, T. (2015). Ahi Evran Üniversitesi Son Sınıf Öğrencilerinin Gelecek Kaygısı ve Umutsuzluklarının Incelenmesi, Yayımlanmamış yüksek lisans tezi, Ahi Evran Üniversitesi Fen Bilimleri Enstitüsü, Kırşehir.

T.C. Çalışma ve Sosyal Güvenlik Bakanlığı Çalışma Genel Müdürlüğü, Asgari Ücretin Net Hesabı ve İşverene Maliyeti. http://www.csgb.gov.tr/home/contents/istatistikler/asgariucret/ adresinden elde edildi.

Tekin, M. ve Filiz, K. (2008). Beden Eğitimi ve Spor Yüksekokullarının Antrenörlük Eğitimi ve Spor Yöneticiliği Bölümlerinde Öğrenim Gören Öğrencilerin Umutsuzluk ve Boyun Eğici Davranış 
Düzeylerinin Çeşitli Değişkenlere Göre İncelenmesi. Spormetre Beden Eğitimi ve Spor Bilimleri Dergisi, 6(1), 27-37.

Tümkaya, S., Çelik, M. ve Aybek, B. (2011). Lise Öğrencilerinde Boyun Eğici Davranışlar, Otomatik Düşünceler, Umutsuzluk ve Yaşam Doyumunun Incelenmesi. Çukurova Üniversitesi Sosyal Bilimler Enstitüsü $\quad$ Dergisi, 20 20(2), 77-94. http://sbeski.cu.edu.tr/dergi/dosyalar/2011.20.2.802.pdf adresinden elde edildi.

Türk-iş Haber Bülteni, Açlık ve Yoksulluk Sınırı. http://www.turkis.org.tr/dosya/QcdLo99Q55t4.pdf adresinden elde edildi.

Üngören, E. ve Ehtiyar, R. (2009). Türk ve Alman Öğrencilerin Umutsuzluk Düzeylerinin Karşısaştırıması ve Umutsuzluk Düzeylerini Etkileyen Faktörlerin Belirlenmesi: Turizm Eğitimi Alan Öğrenciler Üzerinde Bir Araştırma. Journal of Yasar University, 4(14), 2093-2127.

Üstün, G., Dedekoç, Ş., Kaval, T., Öztürk, F., Sapcı, Y. ve Can, S. (2014). Üniversite Son Sinıf Öğrencilerinin İ̧̧ Bulmaya Ilişkin Umutsuzluk Düzeylerinin İncelenmesi. Amasya Üniversitesi Eğitim Fakültesi Dergisi, 3(2), 200-221.

Yalçın, S. ve Açıkgöz, i. (2014). Sağılı Bilimleri Fakültesi Son Sınıf Öğrencilerinin Umutsuzluk Düzeylerinin KarşılaştıııIması. Mustafa Kemal Üniversitesi Sosyal Bilimler Enstitüsü Dergisi, 11 (26), 259-270.

Yenilmez, K. (2010). Ortaöğretim Öğrencilerinin Matematik Dersine Yönelik Umutsuzluk Düzeyleri. Hacettepe Üniversitesi Eğitim Fakültesi Dergisi, 38, 307-317. 